\title{
HR-manager: Prospects for Employment in the Labor Markets
}

\author{
Valentyna Zhukovska ${ }^{1 *}$, Galyna Piatnytska ${ }^{1}$, Natalia Raksha ${ }^{1,2}$, Liudmyla Lukashova ${ }^{1}$, and \\ Olha Salimon ${ }^{3}$ \\ ${ }^{1}$ Kyiv National University of Trade \& Economics, Department of Management, 19 Kyoto str., 02156 \\ Kyiv, Ukraine \\ ${ }^{2}$ Key West University, 10151 Deerwood Park Boulevard, Bldg 200, Suite 250 Jacksonville, \\ FL 32256, USA \\ ${ }^{3}$ Kyiv National University of Trade \& Economics, Department of Hotel and Restaurant Business, \\ 19 Kyoto str., 02156 Kyiv, Ukraine
}

\begin{abstract}
Topical issues of changing the requirements for HR managers in the labor market under the Covid crisis and digital transformation of business have been highlighted. Attention is drawn to the main responsibilities of a modern $\mathrm{HR}$ manager. The problems of communication interaction in the work of HR managers through the transition of employees to online or mixed mode of operation have been identified. An analysis of the supply and demand of HR managers in the labor market of different countries has been conducted. The requirements and benefits for HR manager by the sample of countries have been compared. Particular attention is paid to the work of HR-managers with expats. Distinctive characteristics of an expat in the position of HR manager have been demonstrated. In 2020-2021, the survey of HR managers has been conducted and the skills of the HR manager, which will enable him to be strategically in demand in the labor market and to contribute to the progressive development of both national and international companies have been identified. The objective of the paper is to identify transformations in the work of modern HR-managers and analysis of supply and demand for HR.
\end{abstract}

\section{Introduction}

The pandemic has challenged the expatriate lifestyle that was possible thanks to the freedom of movement between countries and entire continents. Due to the risks of the pandemic, restrictions and quarantines, living abroad is no longer so easy. Many expatriates from all over the world are thinking about returning home. Indeed, the COVID-19 crisis has left expats wondering: what does this whole trip really cost?

It is worth noting that while some people wait for the borders to open, others, especially those who work in accordance with the liberal policy of remote work, use discounted

\footnotetext{
* Corresponding author: valentyna2015@ukr.net
} 
tickets and move to countries around the world. However, a vision of the world, let alone expatriation, requires careful research. It is necessary to consider not only which countries are accepting foreigners, but also factors such as health and social care, the country's response to the pandemic, culture and employment opportunities.

Clearly, unite all above problems in one research paper is challenging. Therefore, in our investigation, we will focus on the issue of employment and its related new opportunities and challenges that modern HR managers face or will face in the near future.

\section{Literature review}

A wide range of scientists and experts rightly point out «economic growth and development is achieved through growth in fixed capital, labor costs, and technological progress» [1, p. 82]. The debates on the role and contribution of HR managers to such economic growth and related costs, both in general and in the management of the activities and development of the various organizations, is long-standing, as evidenced by a publication D. Ulrich [2]. However, analysis of the researches presented in the numerous scientific publications on issues of HR management [2-6, et al.], did not provide a clear answer to the questions: how much the HR manager would need in a strategic perspective, how its functions would not change over time, and how promising it would be to attract expatriates to the positions of managers and other employees of HR services companies. It matters to mention that, in large diversified international companies (such as those that develop in the product retail segment [7]), there is often a need for more than one functionally specialized HR service unit. This often involves a branched HR staff that includes training managers, compensation managers and recruiting managers. With the growing geographical diversification of such a company, the central office of its HR service may well decide to use expats as HR managers in various regional divisions of the company. In other words, HR managers of modern business must have both: the necessary knowledge and practical skills to work with expatriate employees in the company, and to be able to adapt quickly in order to make effective decisions in the management of the company's personnel if they are considered expatriates.

Generally, the employment of a foreign employee requires considerable employer attention (regardless of whether he will hold the position of HR-manager of the company or not). This is primarily due to the special requirements for such a procedure. Note that different countries have their own special regulations governing the employment and work of foreigners. At the same time, emigrants are considered and often perceived exclusively as temporary workers working under temporary contracts in foreign regions [8]. However, their contract can be renewed multiple times [9], and therefore the period of residence and employment in foreign countries is constantly extended.

Employing expatriates, on the one hand, may result, in a disadvantaged position of local labor in seeking employment through expatriate colleagues [3]. This in turn leads to a problem of accumulation of imbalances due to likely growth of unemployment rate, longterm unemployment rate and youth unemployment rate of the country's population, and consequently, negatively affects economic growth and stability of the country [10]. Second, if one compares, for example, the advantages of employing local managers and expatriate managers, then the former, from the point of view of business owners and companies, are shown by the fact that «...they are in a better position to maintain channels of communications with local suppliers and government officials; and they are less expensive to employ than expatriates...» [8, p. 188].

Although some studies such as Lall [11] have shown that even local HR managers in a number of developing countries tend to favor emigrants, limiting local labor. 
On the other hand, the active involvement of highly qualified expatriates is often due to the conditions and challenges faced by business in connection with the deployment of the fourth industrial revolution Fedulova, et al. [12] and its impact on the innovative development of organizations, which is constantly changing and can take new forms [13]. Such scientists as Laursen, et al. [14]; Breschi, et al. [15], by exploring the link between the hiring of highly skilled expatriates and the company's business performance through innovative solutions, they confirmed the hypothesis that the hiring of highly skilled migrants fosters innovation more than skilled local workers. Important issues in the work of modern HR-managers and employment problem solving are the training and development of employees / talents, including taking into account the cultural characteristics of emigrants Martocchio [6]; motivation of their work [3] and social guidelines in the development of companies involving the implementation of various social projects, including aimed at supporting the company's employees in solving socially important problems for them, as well as the formation of a general socially responsible culture of behavior of the company's employees [16].

However, the development of the HR manager himself, including the formation of his brand [17], as well as the motivation of his work can play an equally important role in determining the prospects for changes in the demand for this position and employment in the labor market.

Certain risks that a modern HR manager may face, both personally and in the performance of his duties, are in manifesting the negative consequences of the contradictory relationship between employee engagement and burnout (Anthony-McMann, et al. [18]). Therefore, in determining the prospects of HR-managers on the labor market, it is worth paying special attention to the development and implementation of measures to counteract burnout.

There is a growing body of research on the analysis of trends and challenges in staff digital work. This in turn requires the HR manager to develop digital competences [19, 20]. This has become particularly relevant in the context of the spread of the practice of telecommuting and the effects of the COVID crisis on the work of HR managers. Such scientists as Bieliaieva, et al. [21] have already studied some aspects of changes in the work of enterprises and their HR-services during the COVID crisis, finding that in general enterprises reduce costs in a crisis by reducing production capacity and changing the schedule of employees working day (taking into account daylight hours). Due to the need to switch to remote or mixed mode, no less important to establish the fact that when workplace isolation is high, workers are less accessible to their tasks and consequently their productivity and creativity are reduced [4].

Also, the working conditions of HR managers are becoming more complicated, and in some countries even leads to the need for compensation payments or some kind of benefits or revision of prices for research and development and their transfer [22], which, in particular, may be directly related to the improvement of HR-management in business organizations. In an effort to settle above-mentioned issues and to promote the development of digital competencies of managers (including HR-managers), as well as based on the study of principles and basic approaches to the formation of competencies, scientists [5] in this research paper developed and validated the model of a strategic approach to the development of competencies of industry managers 4.0. It is theoretically proved that HR managers of the new formation should become a key «....intangible components of strategic potential that the enterprise forms and/or develops in order to achieve the set strategic goals» [23, p. 47].

In addition to the demand for highly intelligent personnel with skills to social relations, the communicative skills of employees play a special role in the modern labor market. It is 
been proven that they are «...the key factors of human capital, which promotes the increase in competitiveness of an individual in the labor market...» [24, p. 105].

Despite all the challenges and problems mentioned above, and taking into account the fragmentary nature of most studies, which often concerned only certain aspects of HR management and did not consider the strategic perspectives of HR managers in the labor market, the aim of this paper is to identify transformations in the work of modern HRmanagers and analysis of supply and demand for HR in different areas.

\section{Material and method}

To understand the content of the work of HR managers in the digital transformation of business and COVID crisis was used system analysis. Based on this analysis, a number of features have been identified in relation to the requirements of companies (employers) in different labor markets.

The survey of HR managers has been conducted, and data from job offerings and job search sites has been collected.

To develop an understanding of what factors influence the choice of vacancies for HR managers in a COVID crisis, the level of compensation in various international and global companies in the USA, Ukraine, China and some other countries was analyzed.

Using the method of synthesis, a conclusion was formulated on the concept of causation of successful employment of expatriates, the key functions of HR managers contained in the vacancies of international and national companies as a global representation of the solution to the problem were identified.

\section{Results and discussion}

The transition of workers who worked off-line to a hybrid or online work format has revealed communication problems. The personal work of the vast majority of HR managers during the COVID crisis changed due to the need to adapt to telecommuting and digital challenges with which some companies were unfortunately not ready. In fact, HR managers are faced with the complexities of working in the workplace, as they are remotely obliged to ensure the safety of employees, to obtain the necessary permits, to decide the issues of payment. In some companies, this has been the case for downsizing and lay-offs. Another problem was that many HR teams were not designed to respond flexibly to internal and external clients in the process of recruitment, training, and collaboration with partners.

Due to the necessity of controlling the efficiency the employee's remote work, the HRmanagers have a great responsibility to retain an employee in the company.

Therefore, the HR-manager has to resolve next tasks (additional ones might be in the list depending on the size and structure of the company):

- regular monitoring of the situation on the labor market in terms of trends and the average salary of specialists in various specialties;

- finding staff for the company, responsible for hiring planning and staffing;

- creating a system of employee motivation;

- responsible for the corporate culture: the formation of the socio-psychological climate, the values of employee interest in achieving the overall goals of the company;

- recruiting, interviewing, testing, and selecting employees to fill vacant positions;

- onboarding newcomers to the company;

- supporting employee opportunities for professional development.

Such a specialist must have certain skills: 
a) understanding of psychology and a clear understanding of what personal qualities are needed for a particular specialist to take an vacancy $[3 ; 20 ; 25]$;

b) communication skills for conducting interviews, the ability to relieve mental stress, set a person up for conversation, calm and support;

c) knowing the current labor legislation, the rules of documentation for hiring and firing staff $[20 ; 25]$.

The analysis of supply and demand for vacancies in such countries (USA, Ukraine, Norway, Australia and China) shows their greatest concentration mainly in the capitals and big cities where large companies are concentrated. This, in turn, increases the demand for personnel managers of various qualifications, according to our screening of ads of companies and recruitment agencies on relevant sites [26-34]. The management of international companies applies a relocation policy to effectively use the potential of expatriates in branches of companies in other countries. The results of our research, according to a review of job search sites, allows us to conclude that the number of vacancies offered in the labor market, employers are interested in such HR specializations as: HR Project Manager; Remote HR Manager; HR-Researcher. Today, in the United States of America, the most popular requests for the next specializations: HR analysts, HR managers for talent management, HR managers for compensation management and HR managers for professional development. At the same time, due to the COVID situation the huge number of vacancies in medicine and IT in many countries are available.

The most popular among those looking for a job as an HR manager, in terms of salary are categories such as Global HR and HR Analytics (Fig. 1).

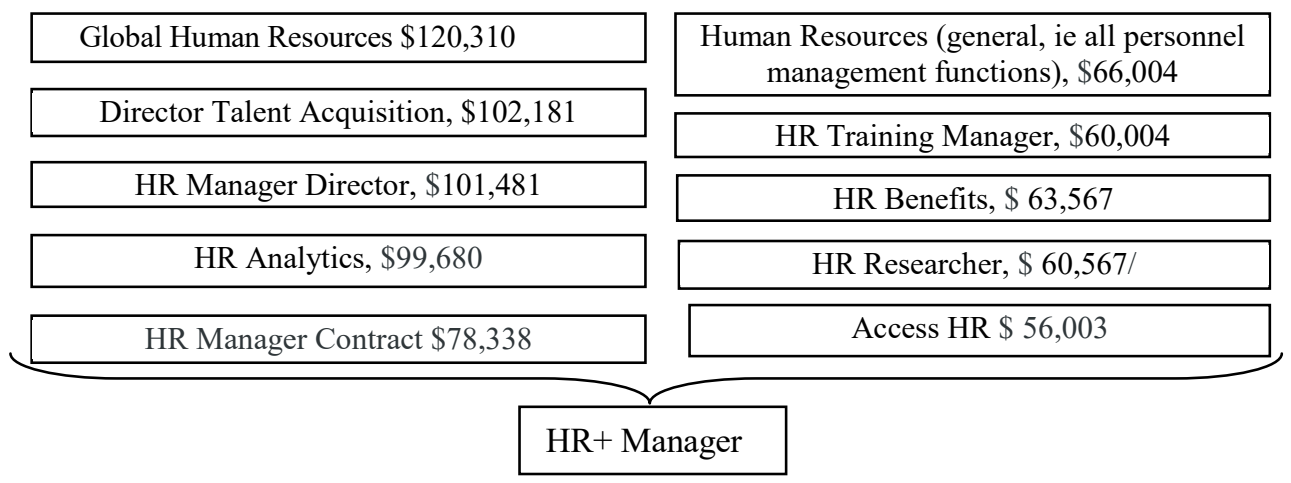

Fig. 1. Top searched job categories for HR with Average Annual Salary per year in USA.

Source: Developed by the authors based on data processing from the HR-site [29].

The data we collected on the Chinese job search site and job offers [30] allowed us to conclude that the salaries of HR managers in China depend not only on the industry affiliation of the company, but also on the location of the office. In addition, HR manager position requires mandatory certification.

The peculiarities of the expat's work in Chinese companies are mainly concentrated in the plane of relations: the necessary basic knowledge of Chinese, the candidate should be diligent, attentive to details, do not demonstrate (do not emphasize) that the level of competence of the expatriate is higher than local employees. Due to collective cultures and team support is the norm. At the same time, given that the polarization of inequality in society is acceptable in China, the company's leaders allow abuse of power. The level of expatriate payments in China loses with respect to the United States, but this is offset by relatively low costs, except for housing in large cities such as Beijing, Shanghai, Shandong. To work for the expatriate's internship in a Chinese company, the average monthly 
expenses (food, accommodation, transportation) are in the range of $\$ 300-550$, depending on the rent. The cross-cultural context of the interaction plays an important role for the expatriate. Successful employment usually results from previous internships, including student exchange programs or temporary work during studies.

It should be noted that the average salary of an HR manager in China is in the top 10 in the ranking of salaries in the country, ranking seventh [27]. To obtain the position of HRmanager the expatriate should have a bachelor's degree with at least 5 years of experience, including the need to have experience in recruiting online.

In China, as well as in many other countries around the world, the position of HR manager provides additional payments for productivity. Among the current competencies of these managers for powerful companies are required multitasking competencies such as analytical and strategic thinking in the recruitment process, knowledge of the company's business and focus on results, energy and stress, as well as the ability to withstand external pressure and a sense of teamwork.

Analyzing the initial requirements for an expatriate to work as an HR manager in Ukraine, it should be noted that international certification in national and state-owned companies is not required. However, the international HR certification is a kind of pass for career growth in any company where there is such a vacancy.

Ukrainian companies sometimes resort to HR-hunting for having highly qualified HR managers on their staff. The surveys of the main requirements for HR managers in Ukrainian companies showed that in order to hold the position of HR manager, HR business partner or HR director the applicant should have an experience of 5-7 years and preferably one of the international certifications: SHRM, HRCI, CIPD.

Analysis of the top positions salaries of HR managers in national Ukrainian companies shows that the bigger is the company, the higher the salaries. Interesting, that, as a rule, this trend is observed in many other countries. Data analysis from websites and social networks, where proposals for vacancies in Ukraine are presented [31-33], shows that the biggest number of requests for HR-managers is concentrated in Kyiv - the country's capital.

A comparative analysis of professional requirements, work experience, social package and salaries of HR-managers in different countries (table 1) shows that in some positions they coincide, and in others - have significant differences. In addition to the data analyzed in the table 1 we could see that in countries such as Australia, Norway and China, to become an HR manager it is possible to have a bachelor's degree not only in the field of human resources management, but also in the field of psychology and communication. At the same time, Ukrainian employers do not make specific demands for the education of HR-manager. It was only in the requests of some companies that we identified the need for higher education and a degree of manager or psychologist. However, almost all large companies, especially international ones operating in Ukraine, among the main requirements of the HR-manager are the availability of skills in MS Office and other programs, as well as knowledge of the English language.

According to the Table 1, companies are usually looking for HR managers with work experience. At the same time, it should be noted that in top positions in the HR service, employers might require longer working experience - usually 10 years' experience in almost all countries. This is evidenced in particular by our research in trading companies operating in Ukraine: Fozzy Group; ATB-market; Metro Cash \& Carry Ukraine; Auchan Hypermarket Ukraine; etc.

American and Norwegian companies often offer a full package of benefits, including all types of coverage and insurance, paid leave, prepayment for gymnasium activities, etc. Mandatory benefits for workers in Australia include retirement and rest pay, employment leave, maternity and paternity leave, and sick pay. Supplementary benefits for employees 
are also provided for further training and medical insurance. At the same time, HR managers have the flexibly to work [28].

Table 1. Comparison of requirements and benefits for HR-manager by the sample of countries.

\begin{tabular}{|c|c|c|c|c|c|}
\hline \multirow[b]{2}{*}{ Country } & \multicolumn{2}{|c|}{ Requirements } & \multirow{2}{*}{$\begin{array}{l}\text { Benefits } \\
\text { package }\end{array}$} & \multicolumn{2}{|c|}{ Weighted average Salary } \\
\hline & Education & Experience & & $\begin{array}{l}\text { EUR (USD), } \\
\text { per year * }\end{array}$ & $\begin{array}{l}\text { EUR per } \\
\text { month * }\end{array}$ \\
\hline Australia & $\begin{array}{c}\text { bachelor or } \\
\text { diploma-level } \\
\text { qualification (6-12 } \\
\text { months of studying) } \\
\text { in HR } \\
\end{array}$ & $\begin{array}{c}\text { necessary, } \\
5+\text { years }\end{array}$ & $\begin{array}{c}\text { mandatory } \\
\text { pension plans, } \\
\text { education } \\
\text { advancement, } \\
\text { health insurance } \\
\end{array}$ & $\begin{array}{c}56842,4 \\
(69130,0)\end{array}$ & 4736,9 \\
\hline Norway & $\begin{array}{l}\text { bachelor's degree in } \\
\text { HR Management }\end{array}$ & $\begin{array}{c}\text { necessary, } \\
5+\text { years }\end{array}$ & $\begin{array}{l}\text { pension plans, } \\
\text { insurance, } \\
\text { benefits }\end{array}$ & $\begin{array}{c}57643,3 \\
(70104,0)\end{array}$ & 4803,6 \\
\hline China & $\begin{array}{c}\text { bachelor's degree in } \\
\text { human resources }\end{array}$ & $\begin{array}{c}\text { necessary, } \\
5+\text { years }\end{array}$ & medical, drug & $\begin{array}{c}14196,0 \\
(17226,8) \\
\end{array}$ & 1183,0 \\
\hline Ukraine & $\begin{array}{c}\text { most job offers do } \\
\text { not specify an } \\
\text { education; only } \\
\text { some require a } \\
\text { degree in } \\
\text { psychology or } \\
\text { management }\end{array}$ & $\begin{array}{c}\text { necessary, } \\
1-3 \text { years }\end{array}$ & $\begin{array}{c}\text { usually } \\
\text { discounts; some } \\
\text { include } \\
\text { insurance and } \\
\text { other benefits }\end{array}$ & $\begin{array}{c}4978,8 \\
(6054,7)\end{array}$ & 414,9 \\
\hline USA & $\begin{array}{l}\text { bachelor's degree in } \\
\text { human resources, } \\
\text { business } \\
\text { management or } \\
\text { similar; psychology }\end{array}$ & $\begin{array}{l}\text { necessary, } \\
3-5+\text { years }\end{array}$ & $\begin{array}{l}\text { medical, drug, } \\
\text { vision, dental } \\
\text { Coverage; paid } \\
\text { holidays; } \\
\text { employee } \\
\text { discounts }\end{array}$ & $\begin{array}{c}56443,8 \\
(68170,0)\end{array}$ & 4703,7 \\
\hline
\end{tabular}

Source: Developed by the authors based on data processing from the sites [26-32; 34].

Note. ${ }^{*}$ Calculated by the authors taking into account the exchange rates of the sample of studied countries (as of May 3, 2021).

Table. 1 shows average wages of HR managers worldwide. However, it is worth mentioning, that depending on the company and whether the employee is an expatriate, the size of the company may vary. Based on the results of the HSBC Expat Explorer survey conducted in 2018 and referred to by Bloomberg, the largest wages for foreign workers (including HR managers) in Switzerland and the United States (fig. 2).

To conclude the research on the supply and demand of HR managers, we point out that their levels in the labor market are roughly the same. In Ukraine, the USA, Australia or Norway there are quite a few candidates for the position of HR-manager. At the same time, companies are constantly looking for HR-managers, so it is possible to find the desired job.

Evaluating the existing requests for HR-managers in connection with the increase in the volume of virtual communications during the COVID-crisis period, we state that already now and in the future the requirements for candidates for these positions will be substantially revised. Such requirements, in our view, should include the development of knowledge on the application of new approaches to attracting workers through the Internet; the ability to navigate a negative reaction in a difficult situation and cross-cultural navigation; the digital literacy of an advanced professional user; high levels of flexibility and emotional intelligence of an HR-manager. 


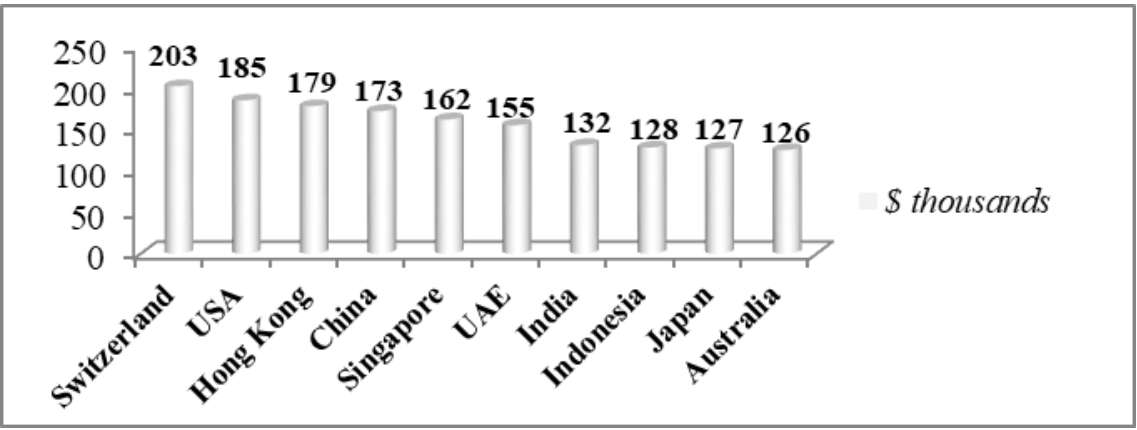

Fig. 2. Top 10 countries with the highest salaries for expats * Source: HSBC Expat Explorer survey.

Note. *The diagram is constructed by the authors based on data from Bloomberg [35].

It is worth pointing out that the pandemic has made adjustments in the work of managers of global international companies, where there is a request for professionals of a certain business sphere and a format of work is maintained. These are industrial production, logistics, processing industries, where specialists in rare specialties are needed to fulfill the company's business tasks, etc. There is also a need for specialists whose competence profile requires knowledge of different languages, cultures, customs, as well as those who are ready for rapid psychological, emotional and physiological adaptation. Often such specialists are employed or absent in local (local) labor markets or it is difficult for a recruiter to search for them within one city or region. In this case, to fulfill the requirements of the company, international HR managers are forced to use specialist relocation or headhunting. Thus, another requirement for modern HR-managers is the availability of effective relocation and headhunting skills.

The key issues that the remote HR recruiter solves are the ability to motivate a future professional to move and to accompany and support onboarding in the workplace. As a rule, when a manager withdraws a request for a relay of a candidate, the customers (employers) sometimes place restrictions on specialists from individual regions and are not always ready to pay for the transfer of a candidate with his or her family. Therefore, new demands are made from the HR Manager in this context for additional competencies: career coaching and consulting, etc. Indispensable competencies in the process of online selection and hiring of talented professionals in the global labor market are assessing the potential of the expatriate in the new environment, basic knowledge of psycho diagnostics and psychometrics, career technology and individual track in professional development, ability to conduct individual coaching, form a well-being program.

In the context of COVID-crisis, as the results of our research have shown, managers of human resources departments of international companies pay special attention to the development of methodological tools for the diagnosis of programs of well-being and involvement of employees. According to the results of some studies $[18 ; 20 ; 25]$ Fortune 500 employees with the best practical experience in implementing well-being programs, receive higher rates of involvement in the workplace process and the effectiveness of the company's business as a whole.

During 2020-2021 the survey of 62 HR-managers of Ukrainian trade companies has been conducted. The results shows that $57 \%$ of interviewers had management experience of 5-7 years, $22 \%-8$ or more years, and the rest - experience of working in HR up to 5 years. Of those interviewed, $38 \%$ of HR Directors had expatriate experience in international companies. 
To the question of the questionnaire: «What are the key competences of the HR manager which determine his success?» The following responses were received:

- motivate and persuade teams to share the company's vision and strategic goals (95\%);

- ability to work in crisis conditions (for example, as a pandemic, sale and merger of the company) to take responsibility for resolving issues under pressure from external and internal stakeholders (76\%);

- interact effectively in a networked digital and cross-cultural environment (84\%);

- achieve effectiveness in conditions of risk and uncertainty (82\%);

- strategic leadership, coaching (67\%).

It should be noted that modern digital trends have also influenced the assignment of personnel managers in the work using various digital chat and HR bots, social networks (in particular with the aim of social media recruitment). This trend has almost doubled over the past two years, according to our estimates.

At the same time, in many industries / spheres of economic activity (for example, medicine, consulting, bank sector, etc.) EU law requires that all information about customer bases, staff, be stored on corporate servers. Therefore, HR managers should be responsible for not disclosing personalized information and for properly administering employee data.

\section{Conclusions}

The study identified the skills of the HR manager, which will enable him to be strategically in demand in the labor market and to contribute to the progressive development of both national and international companies:

1) staff development for improving the culture of innovation and formation of the company's HR brand;

2) involvement of students and graduates in companies with a subsequent job offer;

3) formation of a flexible training system based on online learning (peer-to-peer learning), self-development;

4) introduction of a diversified system of rewards and benefits;

5) environmental transformation of $\mathrm{HR}$ processes in providing living and leisure conditions for employees; creating a favorable online and digital climate;

6) leadership development and talent engagement.

The HR-manager profession is constantly changing. Important for business today is strategic and social leadership, well-being of staff, and therefore the work of the HR manager should be oriented to these trends. An analysis of HR pay levels revealed significant differences in the wages of HR managers in Ukraine and other countries of the world. However, HR managers remain in high demand in many markets around the world, even in the context of the COVID crisis. A new trend in the search requests of HR candidates is the competence to organize and conduct coaching and career counseling for company employees.

\section{References}

1. A. Mazaraki, Y. Drozdova, S. Bay, BJES 6(1), 80-86 (2020). doi: 10.30525/2256-0742/2020-6-180-86

2. D. Ulrich, HBR 76(1), 124-34 (1998)

3. M. Petrova, V. Koval, M. Tepavicharova, A. Zerkal, A. Radchenko, and N. Bondarchuk, JSSI 9(3), 897 (2020). doi: 10.9770/jssi.2020.9.3(15)

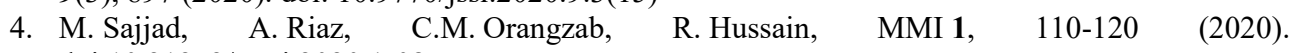
doi:10.21272/mmi.2020.1-08 
5. H. Dzwigol, M. Dzwigol-Barosz, R. Miśkiewicz, A. Kwilinski, ESI 7(4), 2630-2644 (2020). doi: 10.9770/jesi.2020.7.4(5)

6. J. J. Martocchio (ed.), Research in Personnel and Human Resources Management, vol. 24 (Emerald Group Publishing Limited, Bingley, 2005), pp. 305-311

7. G. T. Pyatnytska, Perevahy i nedoliky rozvytku velykykh torhovelnykh merezh na rynku rozdribnoi torhivli prodovolchymy tovaramy (Advantages and drawbacks of large retail chains development at the food commodities market), APE journal, 4(142), 103-113 (2013)

8. C. Ward, S. Bochner, A. Furnham, The Psychology of Culture Shock, 2nd ed. (Routledge, New York, 2001)

9. N, Shah, The management of irregular migration and its consequences for development: Gulf Cooperation Council. (Working Paper No. 19, Regional Office for Asia and the Pacific, ILO, 2009), https://www.ilo.org/asia/publications/WCMS_105105/. Accessed 23 Apr 2021

10. V. Heyets, M. Skrypnychenko, S. Shumska, Makroekonomichni dysbalansy v Ukraini: monitorinh na osnovi MIP Scoreboard te modelni ocinky ikhnoho vplyvu na zrostannya I stabilnist (Macroeconomic Imbalances in Ukraine: MIP Scoreboard Monitoring and Model Estimates of Their Impact on Growth and Stability), FCAPTP, 2(33), 296-305 (2020). doi:10.18371/fcaptp.v2i33.206956

11. S. Lall, The Employment Impact Of Globalisation In Developing Countries. (QEH Working Papers qehwps93, Queen Elizabeth House, University of Oxford, 2002). http://workingpapers.qeh.ox.ac.uk/RePEc/qeh/qehwps/qehwps93.pdf. Accessed 23 Apr 2021

12. I. Fedulova, G. Piatnytska, L. Lukashova, MMI 3, 216-228 (2018). doi:10.21272/mmi.2018.3-19

13. G. Piatnytska, O. Hryhorenko, T. Dolzhenko, Dykhotomiia innovatsiinykh transformatsii pidpryiemstv (Dichotomy of enterprises' innovative transformations), ZTEFP, 2(115), 30-43 (2021). doi:10.31617/zt.knute.2021(115)02

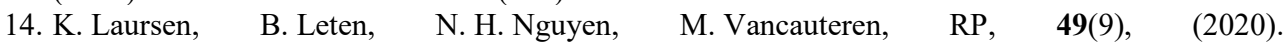
doi:10.1016/j.respol.2020.104034.

15. S. Breschi, C. Lawson, F. Lissoni, A. Morrison, A. Salter, RP, 49(9), (2020). doi:10.1016/j.respol.2020.104070.

16. G. T. Piatnytska, V. M. Zhukovska, Razvitie vnutrennei torhovli: sovremennye transformatsii i prioritety socializatsii (Domestic Trade Development: Current Transformations and Priorities in Socialization). APE journal, 11(173), 106-119. (2015)

17. I. Mykolaichuk, A. Rasulova, Moder Science - Modern veda, 6, 59-70 (2019). https://drive.google.com/file/d/1X6nnuVODnnp9uWbLMjlic9mFVhC-AawA/view. Accessed 23 Apr 2021

18. P. E. Anthony-McMann, A.D. Ellinger, M. Astakhova, J.R. Halbesleben, HRDQ, 28(2), 163-195 (2017). doi:10.1002/hrdq.21276

19. V. M. Zhukovska, Tsifrovi vyklyky kadrovoho zabezpechenya pidpryemstva (Digital challenges of the staffing support of the company), SMEU, 1(2), 10-17 (2019). doi:10.23939/smeu2019.02.010

20. V. M. Zhukovska, Sotsialnyi rozvytok orhanizatsii: potentsial, upravlinnya, innovatsii (Social development of the organization: potential, management, innovation). (Kyiv: KNUTE, 2018).

21. N. Bieliaieva, M. Krushelnytskyi, L. Voliak, N. Usata, O. Sova, IJMP, 11(9), 2275-2290 (2020). doi:10.14807/ijmp.v11i9.1414

22. O. Mrykhina, L. Lisovska, I. Novakivskyj, A. Terebukh, V. Zhukovska，ASTES，5(5)，80-93 (2020). doi:10.25046/aj050512

23. G. Piatnytska, K. Yatsyshyna, V. Berezin, HERALD of KNUTE, 4(126), 42-56 (2019). doi:10.31617/visnik.knute.2019(126)04

24. V. Koval, Y. Polyezhayev, A. Bezkhlibna, BJES, 4(5), 105-113 (2018). doi:10.30525/22560742/2018-4-5-105-113

25. Leadership Academy, How Steward Leaders Identify and Prevent Burnout in the Workplace (2021), https://fullsailleadership.com/employee-engagement/. Accessed 2 May 2021

26. Work.ua (HR-manager, Ukraine, 2021), https://www.work.ua/en/jobs-hr-manager/?setlp=en. Accessed 2 May 2021

27. Payscale, How to pay remote Workers (2021), https://www.payscale.com/data/remote-work. Accessed 2 May 2021

28. CA Financial, Mandatory Employee Benefits in Australia. (Asinta, 2021), https://www.asinta.com/countries/australia. Accessed 2 May 2021 
29. Ziprecruiter (Hr+Manager, Chicago, 2021), https://www.ziprecruiter.com/Jobs/Hr-Manager. Accessed 2 May 2021

30. Baipin in news ( Baidu, China, 2021), https://zhaopin.baidu.com/daily?tab=0. Accessed 7 May 2021

31. Job search site (Work.ua,Ukraine, 2021), https://www.work.ua/. Accessed 7 May 2021

32. Job search site (rabota.ua, Ukraine, 2021),https://rabota.ua/. Accessed 2 May 2021

33. Social network (Linkedin.com, 2021), https://www.linkedin.com/. Accessed 2 May 2021

34. International job search site (Glassdoor.com, 2021), https://www.glassdoor.com/index.htm. Accessed 2 May 2021

35. Bosley, C. These Are the Best Countries to Live and Work in - And to Boost Your Salary. (Bloomberg,2018),https://www.bloomberg.com/news/articles/2018-10-10/want-a-21-000-payraise-hsbc-recommends-you-move-overseas. Accessed 2 May 2021 